\title{
The influence of obesity on the recurrence of cancer in HER-2 positive breast cancer patients related to adjuvant trastuzumab treatment
}

\author{
Obezitenin HER-2 pozitif meme kanseri hastalarında adjuvan trastuzumab tedavisi \\ ile ilişkili olarak tümör nüksüne etkisi
}

\author{
Gamze Gököz Doğu*, Aysegül Kargı**, Arzu Yaren*, Burcu Yapar Taşköylü*, A.Gökcen Demiray* \\ * Pamukkale Üniversitesi Tıp Fakültesi, lç Hastalıkları AD, Tıbbi Onkoloji BD, Denizli \\ ** Denizli Devlet Hastanesi, Medikal Onkoloji Bölümü, Denizli
}

\begin{abstract}
Purpose: Trastuzumab, a humanized monoclonal antibody, was shown to prolong survival in female HER-2 positive early stage breast cancer patients. We examined whether obesity had an influence on the recurrences of HER-2 positive patients, as related to adjuvant trastuzumab treatment, retrospectively.

Materials and methods: Among HER-2 positive 170 patients, 129 had accessible data, and with 114, recorded weight / height measurements were statistically analyzed.

Results: Of these, the body mass index (BMI) was $<30 \mathrm{~kg} / \mathrm{m}^{2}$ in 68 (60\%), and $\geq 30 \mathrm{~kg} / \mathrm{m}^{2}$ in 46 (40\%). Recurrence-free survival (RFS) was $8.8 \pm 6.5$ and $78.09 \pm 12.43$ months in the groups with low and high BMI, respectively $(p=0.32)$. Recurrences were found in 7 of $95(7.4 \%)$ receiving Trastuzumab and 13 of 34 patients $(38.2 \%)$ not receiving. The difference was significant $(p<0.001)$. We detected that 53 patients have a carcinoma insitu on the pathological report $(32$ patients were BMl<30 kg/ $\mathrm{m}^{2}$ group and 21 patients were BMI $\geq 30 \mathrm{~kg} / \mathrm{m}^{2}$ group). Cox regression analysis showed that only presence of carcinoma in situ was significant for PFS, in the population of the study, HR $0.44(95 \% \mathrm{Cl} 1.05-34.28, p=0.044)$. There was a significant relationship favoring trastuzumab treatment between size of tumor $(p=0.04)$ and hormone receptor positivity with RFS $(p=0.002)$. Moreover, in the hormone receptor negative group, the risk of recurrence was 7.6 folds in the absence of trastuzumab treatment. Median follow-up was 24 months (range 3-257) and recurrence was found in 20 patients (15.5\%). Five patients died during follow-up. Presence of carcinoma-in-situ and use of Trastuzumab had influenced RFS in the population of the study. Rate of hormone receptor negativity was higher and RFS was longer in obese patients than non-obese patients; however, the difference was not significant $(p=0.659)$.

Conclusion: Trastuzumab is effective in breast cancer patients to prevent the recurrence, particularly in hormone receptor negative patients.
\end{abstract}

Pam Med J 2013;6(1):5-11

Key words: Adjuvant therapy, HER-2, breast cancer, trastuzumab, obesity

Özet

Amaç: Humanize monoklonal bir antikor olan trastuzumabın, HER-2 pozitif erken evre meme kanseri tanılı kadınlarda sağkalımı uzattığı gösterilmiştir. Retrospektif olarak HER-2 pozitif meme kanserinde trastuzumabın etkisinin obezite ile değişip değişmediğini araştırdık.

Gereç ve yöntem: HER-2 pozitif 170 hastanın 129'unun verilerine ulaşılabildi ve 114 hastanın istatistik analiz için kayıtlardan bulunabilen boy/kilo ölçümleri elde edilebildi. Bu hastalardan vücut kitle indeksi (VKI) $<30 \mathrm{~kg} / \mathrm{m}^{2}$ olan grupta $68(60 \%)$ hasta ve $\geq 30 \mathrm{~kg} / \mathrm{m}^{2}$ olan grupta $46(40 \%)$ hasta mevcuttu.

Bulgular: Progresyonsuz sağkalım VKI $<30 \mathrm{~kg} / \mathrm{m}^{2}$ olan grupta $8.8 \pm 6.5$ ay iken, VKI $\geq 30 \mathrm{~kg} / \mathrm{m}^{2} \mathrm{grupta} 78.09 \pm 12.43$ ay olarak hesaplandı ve aradaki fark istatistiksel olarak anlamlı değildi $(p=0.32)$. Trastuzumab verilen 95 hastanın 7 'sinde (\%7.4) progresyon saptanırken, verilmeyen grupta 34 hastanın 13'ünde (\%38.2) progresyon mevcuttu. Aradaki fark istatistiksel olarak anlamlıydı $(p<0.001)$. Karsinoma insitu saptanan 53 hastanın 32 'si VKi $<30$ kg/m² olan grupta, 21 'I de VKI $\geq 30 \mathrm{~kg} / \mathrm{m}^{2}$ olan grupta idi. Cox regresyon analizinde ise sadece karsinoma insitu varlığı ile progresyonsuz sağkalım arasında anlamlı ilişki mevcuttu. [HR $0.44(95 \% \mathrm{Cl} 1.05-34.28, p=0.044)$ ]. Trastuzumab tedavisi ile tümör çapı $(p=0.04)$, hormone reseptör pozitiflik durumu ile progresyonsuz sağkalım arasında anlamlı ilişki saptandı $(p=0.002)$. Ayrıca, hormone reseptör negatif olan hastalarda Trastuzumab almadıkları takdirde, nüks riskinin 7.6 kat arttığı saptandı. Takip süresi median 24 ay (sınırlar 3-257 ay) olup, 20 hastada (\%15.5) nüks saptandı. Takipte 5 hasta ex oldu. Tüm hasta grubunda Trastuzumab kullanımı ve karsinoma insitu varlığı progresyonsuz sağkalımla ilişkili idi. Hormon reseptör negatifliği ve progresyonsuz sağkalım obez hastalarda daha uzundu ama aradaki fark anlamlı değildi $(p=0.659)$.

Sonuç: Trastuzumab, meme kanserinde özellikle hormon reseptör negatif olan hastalarda progresyonu önlemede etkili bulundu.

Pam Tıp Derg 2013;6(1):5-11

Anahtar sözcükler: Adjuvan tedavi, HER-2, meme kanseri, trastuzumab, obezite

Gamze Gököz Doğu

Yazışma Adresi: Pamukkale Üniversitesi Tıp Fakültesi, İç Hastalıkları AD,Tıbbi Onkoloji BD, Denizli

e-mail: ggd2882@gmail.com

Gönderilme tarihi: 02.02.2012

Kabul tarihi: 11.07 .2012 


\section{Introduction}

Breast cancer is the most common cancer in women. Early detection, improved chemotherapeutic regimens, and targeted treatments like trastuzumab, have resulted in substantial improvements in the survival of patients with breast cancer.

It was reported that positive association has been detected between obesity and breast cancer in postmenopausal women $[1,2]$. Body mass index (BMI) is widely used to define obesity clinically. Obesity is defined as the calculated $\mathrm{BMI}$ value (weight $[\mathrm{kg}] /$ body surface area $\left.\left[\mathrm{m}^{2}\right]\right) \geq 30 \mathrm{~kg} / \mathrm{m}^{2}$ [3]. Obesity is directly related to breast cancer in postmenopausal women, while it was reported in several studies that obesity is inversely related with breast cancer in premenopausal patients [4-8]. In a study conducted in Norway and Sweden, this finding was validated, excluding breast cancer patients with familial history [6]. It has been suggested that dual effect of obesity related to menopausal status. Authors advocated that this condition could be valid only for developed countries and young obese patients $[7,8]$. Obesity has a worse outcome on prognosis of women diagnosed to have early stage breast cancer $[1,9,10]$. It has been suggested that breast carcinoma patients who were in the highest quartile of BMI were 2.5 times as likely to die of their disease within 5 years of diagnosis compared with women in the lowest quartile of BMI [11].

Trastuzumab, a monoclonal antibody against HER-2 (also called CerbB2 or neu), has shown survival benefits in patients with HER2-positive early and metastatic breast cancer [12]. HER-2 over expression is correlated with poorly differentiated, high-grade tumors and lymph node involvement $[13,14]$. HER-2 positive breast cancer patients have a worse prognosis than HER-2 negative breast cancer counterparts.

The aim of this study was to retrospectively evaluate the association between BMI and recurrence of breast cancer in HER-2 positive patients as related to adjuvant trastuzumab treatment.

\section{Materials and methods}

Medical records of female patients with AJCC stage 1-3, HER-2 positive breast cancer who applied for treatment to Oncology Outpatient Clinic, School of Medicine, Pamukkale University and Denizli State Hospital between March 2001 and March 2010 were retrospectively examined.
HER-2 positivity was confirmed by either immunohistochemical and/or FISH analysis.

Weight/height measurements, detailed treatments and histopathological data of tumor were recorded to SPSS 17 pack software. BMI values of patients were classified as obese (BMI $\geq 30 \mathrm{~kg} / \mathrm{m}^{2}$ ) and non-obese according to World Health Organization (WHO) criteria. The $\mathrm{WHO}$ defines $\mathrm{BMI}$ classes as underweight (BMI <18.5 kg/m²), normal (BMI 18.5-24.9 kg/ $\mathrm{m} 2$ ), overweight (BMI 25-29.9 $\mathrm{kg} / \mathrm{m}^{2}$ ), and obese (BMI $\geq 30 \mathrm{~kg} / \mathrm{m}^{2}$ ). For the purposes of the current analysis and because of the low number of patients, the underweight, normal and overweight BMI classes were categorized as "non-obese".

BMI was computed by dividing the weight in kilograms by the square of the height in meters. BMI groups (obese or not) were analyzed using the Pearson chi-square test for categorical variables. All statistical analyses were performed with SPSS.17 software pack. Univariate proportional hazards models were used to examine associations between potential confounders and the time-to event endpoints. The influence of baseline factors on treatment effects was assessed by testing for interactions with treatment in Cox proportional hazards models for recurrence free survival (RFS). Covariates included hormone receptor status (ER and/or PR positivity) tumor size, presence of carcinoma in situ, BMI, trastuzumab therapy, number of metastatic lymph nodes, menopausal status and tumor grade. Kaplan-Meier curve for RFS was constructed and compared using the log-rank test. All analyses were by intention to treat. All $p$ values and Cls were two sided. $\mathrm{P}$ values below 0.05 were considered significant.

\section{Results}

Among HER-2 positive 170 patients, 129 had accessible data and 114 with recorded weight / height measurements were statistically analyzed. Median age for all patients was 49 years (range 27-78). Chemotherapy was not administered to 7 patients. Forty two patients received anthracycline + trastuzumab and 77 patients received anthracycline + taxane + trastuzumab, while 3 patients received CMF regime. When trastuzumab was given, it was administered following chemotherapy. Of patients, 43 subjects did not receive radiotherapy. All patients examined for BMI had received chemotherapy. Characteristics features of obese and non-obese patients, as indicated by BMI values, are given in Table 1. 
Table 1. Patient characteristics by body mass index (BMI) category

\begin{tabular}{|c|c|c|c|}
\hline Characteristic & $\mathrm{BMI} \geq 30 \mathrm{~kg} / \mathrm{m}^{2}$ & $\mathrm{BMI}<30 \mathrm{~kg} / \mathrm{m}^{2}$ & $p$ \\
\hline \multirow[t]{2}{*}{ Mean age (years) } & $51.1 \pm 9.3$ & $48.8 \pm 10.9$ & 0.236 \\
\hline & No. of Patients (\%) & No. of Patients (\%) & \\
\hline All patients & $46(40)$ & $68(60)$ & \\
\hline \multicolumn{4}{|l|}{ Menopausal status } \\
\hline Premenopausal & 28 & 46 & 0.737 \\
\hline Postmenopausal & 18 & 22 & \\
\hline \multicolumn{4}{|l|}{ Tumor size } \\
\hline$\leq 2 \mathrm{~cm}$ & 25 & 39 & 0.433 \\
\hline$>2 \mathrm{~cm}$ & 21 & 29 & \\
\hline \multicolumn{4}{|l|}{ Grade } \\
\hline $1 / 2$ & 14 & 31 & 0.374 \\
\hline 3 & 15 & 22 & \\
\hline Unknown & 17 & 15 & \\
\hline \multicolumn{4}{|c|}{ No. of involved lymph nodes } \\
\hline 0 & 16 & 13 & 0.106 \\
\hline$\geq 1$ & 30 & 55 & \\
\hline \multicolumn{4}{|c|}{ Lymphovascular Invasion } \\
\hline Yes & 12 & 18 & 0.628 \\
\hline No & 18 & 29 & \\
\hline Unknown & 16 & 21 & \\
\hline \multicolumn{4}{|l|}{ Carcinoma insitu } \\
\hline Yes & 21 & 32 & 0.680 \\
\hline No & 25 & 36 & \\
\hline \multicolumn{4}{|c|}{ Hormon receptor positivity } \\
\hline Yes & 17 & 43 & $0.002^{*}$ \\
\hline No & 28 & 25 & \\
\hline Unknown & 1 & & \\
\hline \multicolumn{4}{|l|}{ Stage } \\
\hline I & 7 & 12 & 0.735 \\
\hline II & 11 & 17 & \\
\hline III & 16 & 36 & \\
\hline Unknown & 12 & 3 & \\
\hline \multicolumn{4}{|l|}{ Trastuzumab therapy } \\
\hline Yes & 35 & 60 & 0.639 \\
\hline No & 11 & 8 & \\
\hline \multicolumn{4}{|l|}{ Recurrence } \\
\hline Yes & 8 & 12 & 0.659 \\
\hline No & 38 & 46 & \\
\hline
\end{tabular}


Patients were divided into 2 groups with regards to BMI. In the group with BMI $\geq 30 \mathrm{~kg} / \mathrm{m}^{2}$, hormone receptor negativity was significantly higher $(p=0.002)$. There was no significant difference in-between the two groups as regard to other parameters.

In the group with BMI $\geq 30 \mathrm{~kg} / \mathrm{m}^{2}$, ER negativity rate was increased 2.2 folds $(\mathrm{OR}, 95 \% \mathrm{Cl} 1.32-$ 3.91, $p=0.001)$.

Recurrence-free survival was $8.8 \pm 6.5$ months $(95 \% \mathrm{Cl} 75.4-100.9)$ in the group with $\mathrm{BMI}<30$, while it was $78.09 \pm 12.43(95 \% \mathrm{Cl}$ $53.72-102.45)$ in the group with $\mathrm{BMI} \geq 30$ and the difference was not significant $(p=0.32)$.

When univariate analysis was performed (Table 2), disease recurrence was found in 7 of 95 patients $(7.4 \%)$ receiving Trastuzumab and 13 of 34 patients $(38.2 \%)$ not receiving Trastuzumab. The difference was significant HR 0.12(95\% Cl 0.046-0.362, $p<0.001)$. Cox regression analysis showed that (Table 3 ), only the presence of carcinoma in situ was found to be significantly related with RFS (HR 0.44 (95\% Cl 1.05-34.28, $p=0.044$ ).

When the patients were analyzed as regard to receiving (95 patients, $74 \%$ ) and not receiving (33 patients, 26\%) trastuzumab therapy, a significant relationship favoring trastuzumab treatment in-between RFS and both tumor size $(p=0.04)$ and hormone receptor positivity with ( $p$ $=0.02$ ) were detected. Moreover, in the hormone receptor negative group, the risk of recurrence was 7.6 folds $(95 \% \mathrm{Cl} 2.38-24.8)$ higher, in the absence of trastuzumab treatment.

Median follow-up was 24 months (range 3-257) and recurrence was found in 20 patients (15.5\%). Five patients died during follow-up. Mean RFS was $89.1 \pm 6.5$ months $(95 \% \mathrm{Cl}$, 3-124 months) and overall survival was 213.6 \pm 18.5 months $(95 \% \mathrm{Cl}, 117.2-250.0$ months). Overall survival was not further analyzed since adequate follow-up period could not be reached.

\section{Discussion}

Endogenous sex hormones are regarded as an important risk factor in development of breast cancer [15]. Considering studies conducted on same subject in the literature, there are studies indicating both positive relationship [15-19] and no relationship [20,21] with estradiol and breast cancer in postmenopausal patients. Data indicating increased risk with obesity in the development of postmenopausal breast cancer is present in literature [4,5]. There are not only studies indicating positive relationship between level of estrogen and BMI [22,25], but there are also studies indicating no relationship $[26,27]$. However, the condition that is valid for premenopausal patients is not clearln current study, we aimed to examine the influence of obesity on prognosis of HER-2 positive breast cancer as regard to trastuzumab treatment.

We divided patients with early stage HER2 positive breast cancer into two groups with regards the $\mathrm{BMI}$ score, including subjects with $\mathrm{BMI} \geq 30 \mathrm{~kg} / \mathrm{m}^{2}$ and with $\mathrm{BMI}<30 \mathrm{~kg} / \mathrm{m}^{2}$. A significant relationship was found only between hormone receptor positivity and $\mathrm{BMI}(p=0.002)$. Hormone receptor was positive in $38 \%$ of patients in $B M I \geq 30 \mathrm{~kg} / \mathrm{m}^{2}$ group and in $63 \%$ of patients in $\mathrm{BMl}<30 \mathrm{~kg} / \mathrm{m}^{2}$ group. On the contrary to finding of our study, obesity has stronger positive relationship with hormone receptor positivity in postmenopausal women [28, 29]. This can be related with low number of patients and bias in pathological examination.

The positive effect of adjuvant trastuzumab administration on survival of HER-2 positive breast cancer patients was shown with prospective studies and the agent was introduced to routine administration [30-33]. The only effective parameter in univariate analyses of our current study was the presence of trastuzumab treatment $(p<0.001)$. When patients were re-examined in two groups including patients receiving and not receiving trastuzumab, the recurrence risk was increased 7.6 folds in non-treated patients particularly in hormone receptor negative group $(95 \% \mathrm{Cl} 2.38-$ 24.8). A significant relationship was present inbetween RFS and both tumor size $(p=0.04)$ and hormone receptor positivity with $(p=0.02)$ No relationship was found between trastuzumab treatment and other histopathological features.

In Cox regression analysis, only the presence of carcinoma in situ was statistically significant (Table 3).

In tumours containing both IDC (Invasive Ductal Carcinoma) and DCIS (Ductal Carcinoma Insitu), it is unclear whether or not the IDC component arises directly from DCIS. Some studies showed DCIS as the precursor of IDC-DCIS based tumors according to immunhistochemistry or genomic data [34,35]. Other studies have reported differences between DCIS and IDC-DCIS [36]. These studies suggest that DCIS might not be a precursor of the invasive cancer. One recent study showed that IDC co-existing with DCIS was characterized by 
Table 2. Univariate model results for recurrence free survival

\begin{tabular}{|c|c|c|c|c|}
\hline Variable & No. of patients & No. of events & HR (\%95 CI)* & $p$ \\
\hline \multicolumn{5}{|c|}{ Hormon reseptor status } \\
\hline Positive & 72 & 8 & $1.14(0.80-2.41$ & 0.178 \\
\hline Negative & 56 & 11 & & \\
\hline \multicolumn{5}{|c|}{ Metastatic lymph nodes } \\
\hline Yes & 95 & 17 & $2.25(0.616-8.231)$ & 0.276 \\
\hline No & 34 & 3 & & \\
\hline \multicolumn{5}{|l|}{ Tumor grade } \\
\hline $1-2$ & 45 & 4 & $2.39(0.642-8.914)$ & 0.210 \\
\hline 3 & 37 & 7 & & \\
\hline \multicolumn{5}{|l|}{ Carcinoma insitu } \\
\hline Yes & 55 & 10 & $1.17(0.737-1.871)$ & 0.469 \\
\hline No & 74 & 10 & & \\
\hline \multicolumn{5}{|l|}{$B M I \geq 30 \mathrm{~kg} / \mathrm{m}^{2}$} \\
\hline Yes & 46 & 8 & $1.24(0.438-3.311)$ & 0.659 \\
\hline No & 68 & 12 & & \\
\hline \multicolumn{5}{|c|}{ Trastuzumab therapy } \\
\hline Yes & 95 & 7 & $0.12(0.046-0.362)$ & $<0.001^{*}$ \\
\hline No & 34 & 13 & & \\
\hline \multicolumn{5}{|l|}{ Menopausal status } \\
\hline Premenopausal & 81 & 12 & $1.15(0.433-3.051)$ & 0.779 \\
\hline Postmenopausal & 48 & 8 & & \\
\hline
\end{tabular}

Table 3. Cox regression analysis results for recurrence free survival

\begin{tabular}{llll}
\hline & HR & \%95 Cl & p \\
\hline Hormone receptor status (positive vs negative) & 2.17 & $051-9.2$ & 0.29 \\
Tumor size $(>2 \mathrm{~cm}$ vs $\leq 2 \mathrm{~cm})$ & 1.41 & $0.2-8.8$ & 0.70 \\
Detection of carcinoma insitu (yes vs no) & 0.44 & $1.05-34.28$ & $0.044^{*}$ \\
BMI $\left(\geq 30 \mathrm{~kg} / \mathrm{m}^{2}\right.$ vs $\left.<30 \mathrm{~kg} / \mathrm{m}^{2}\right)$ & 1.05 & $0.17-6.19$ & 0.95 \\
Trastuzumab therapy (yes vs no) & 1.43 & $0.26-7.80$ & 0.68 \\
No. of metastatic lymph nodes $(\geq 4$ vs<4) & 1.32 & $0.25-6.87$ & 0.73 \\
Menopausal status (pre- vs postmenopausal) & 2.16 & $0.43-10.70$ & 0.34 \\
Tumor grade (3 vs 1-2) & 0.45 & $0.11-1.8$ & 0.26 \\
\hline
\end{tabular}

lower proliferation and metastatic potential than pure IDC [37]. Moreover, HER-2 expression and ER expression tend to be inversely related. This finding suggests that mitogenic signaling is important. But authors emphasis that whether IDC-DCIS is a useful independent prognostic markır or not should be remain speculative. For that reason, it is too early to make a decision on this topic. Future work is to explore molecular explanations in natural history with molecular development and differences between DCIS and IDC-DCIS. The median follow-up time is too short to expect major differences in diseasefree survival and overall survival in our study. We were unable to find any study that reported any association among DCIS-IDC, BMI, and 
Trastuzumab therapy. Trastuzumab treatment of seventy six patients was completed and other patients were still receiving treatment when analysis was conducted. Potential limitations of this study are the possibility of detection bias, low number of patients and non-completion of trastuzumab treatment by all patients when analysis was conducted.

In current study, it was found that trastuzumab is effective in breast cancer patients to prevent the recurrence, particularly in hormone receptor negative patients. Effect of BMI on disease-free survival was not significant ( $p=0.659)$. Survival analysis was not conducted since adequate number of patients could not be reached.

We suggest that studies with larger patient populations would be conducted for analyzing the relationships among BMI, presence of carcinoma insitu and menopausal and hormone receptor status' in HER-2 positive breast cancer patients.

Conflict of interest: The authors declared no conflict of interest.

\section{References}

1. Petrelli JM, Calle EE, Rodriguez C, Thun MJ. Body mass index, height, and postmenopausal breast cancer mortality in a prospective cohort of US women. Cancer Causes Control 2002;13:325-332.

2. Borugian MJ, Sheps SB, Kim-Sing C, et al. Waist-tohip ratio and breast cancer mortality. Am J Epidemiol. 2003;158:963-968.

3. Clinical guidelines on the identification, evaluation, and treatment of overweight and obesity in adults: executive summary: Expert Panel on the Identification, Evaluation, and Treatment of Overweight in Adults. Am J Clin Nutr 1998;68:899-917.

4. Cleary MP, Maihle NJ. The role of body mass index in the relative risk of developing premenopausal versus postmenopausal breast cancer. Proc Soc Exp Biol Med 1997;216:28-43.

5. Ursin G, Longnecker MP, Haile RW, Greenland S. A meta-analysis of body mass index and risk of premenopausal breast cancer. Epidemiology 1995;6:137-141.

6. Weiderpass E, Braaten T, Magnusson $C$ et al. A prospective study of body size in different periods of life and risk of premenopausal breast cancer. Cancer Epidemiol Biomarkers Prev 2004;13:1121-1127.

7. Pathak DR, Whittemore AS. Combined effects of body size, parity, and menstrual events on breast cancer incidence in seven countries. Am J Epidemiol 1992;135:153-168.

8. Peacock SL, White E, Daling JR, Voigt LF, Malone KE. Relation between obesity and breast cancer in young women. Am J Epidemiol 1999;149:339-346.
9. Berclaz G, Li S, Price KN, et al. Body mass index as a prognostic feature in operable breast cancer: the International Breast Cancer Study Group Experience. Ann Oncol 2004;15:875-884.

10. Kroenke $\mathrm{CH}$, Chen WY, Rosner B, Holmes MD: Weight, Weight Gain, and Survival After Breast Cancer Diagnosis. J Clin Oncol 2005;23:1370-1378.

11. Daling JR, Malone KE, Doody DR, Johnson LG, Gralow JR, Porter PL: Relation of body mass index to tumor markers and survival among young women with invasive ductal breast carcinoma. Cancer 2001;2:720729.

12. Mackey J, McLeod D, Ragaz J, et al. Adjuvant targeted therapy in early breast cancer. Cancer 2009;115: 1154-1168.

13. Yarden $Y$, Sliwkowski MX. Untangling the ErbB signaling network. Nat Rev Mol Cell Biol 2001;2: 127-137.

14. Gschwind A, Fischer OM, Ullrich A. The discovery of receptor tyrosine kinases: targets for cancer therapy. Nat Rev Cancer 2004;4:361-370.

15. Endogenous Hormones and Breast Cancer Collaborative Group, Key TJ, Appleby PN, Reeves GK et al. .Circulating sex hormones and breast cancer risk factors in postmenopausal women: reanalysis of 13 studies. Br J Cancer 2011;105:709-722.

16. Berrino F, Muti $P$, Micheli $A$, et al. Serum sex hormone levels after menopause and subsequent breast cancer. J Natl Cancer Inst 1996;88:291-296.

17. Dorgan JF, Stanczyk FZ, Longcope C, et al. Relation of prediagnostic serum estrogen and androgen levels to breast cancer risk. Cancer Epi Biomark Prev 1996;5:533-539.

18. Helzlsouer KJ, Alberg AJ, Bush TL, Longcope C, Gordon GB, Comstock GW. A prospective study of endogenous hormones and breast cancer. Cancer Detect Prev 1994;18:79-85.

19. Toniolo PG, Levitz M, Zeleniuch-Jacquotte A, et al. A prospective study of endogenous estrogens and breast cancer in postmenopausal women. J Natl Cancer Inst 1995;87:190-197.

20. Wysowski DK, Comstock GW, Helsing KJ, Lau HL. Sex hormone levels in serum in relation to the development of breast cancer. Am J Epidemiol 1987;125:791-799.

21. Garland CF, FriedlanderNJ, Barrett-Connor E, Khaw KT. Sex hormones and postmenopausal breast cancer: a prospective study in an adult community. Am J Epidemiol 1992;135:1220-1230.

22. Ingram DM, Nottage EM, Willcox DL, Roberts A. Oestrogen binding and risk factors for cancer. $\mathrm{Br} \mathrm{J}$ Cancer 1990;61:303-337.

23. Cauley JA, Gutai JP, Kuller LH, LeDonne D, Powell JG. The epidemiology of serum sex hormones in postmenopausal women. Am J Epidemiol 1989;129:1120-1231.

24. Hankinson SE, Willett WC, Manson JE, et al. Alcohol, height, and adiposity in relation to estrogen and prolactin levels in postmenopausal women. J Natl Cancer Inst 1995;87:1297-1302. 
25. Lipworth L, Adami HO, Trichopoulos D, Carlström K, Mantzoros C. Serum steroid hormone levels, sex hormonebinding globulin, and body mass index in the etiology of postmenopausal breast cancer. Epidemiology 1996;7:96-100.

26. Ernster VL, Wrensch MR, Petrakis NL et al. Benign and malignant breast disease: Initial study results of serum and breast fluid analyses of endogenous estrogens. J Natl Cancer Inst 1987;79:949-960.

27. Newcomb PA, Klein R, Klein BE et al. Association of dietary and life-style factors with sex hormones in postmenopausal women. Epidemiology 1995;6: 318-321.

28. Rose DP, Komninou D, Stephenson GD 2004 Obesity, adipocytokines, and insulin resistance in breast cancer. Obes Rev 2004;5:153-165.

29. Ahn J, Schatzkin A, Lacey Jr JA, et al. Adiposity, adult weight change, and postmenopausal beast cancer risk. Arch Intern Med 2008;167:2091-2100.

30. Piccart-Gebhart MJ, Procter M, Leyland-Jones B, et al. Herceptin Adjuvant (HERA) Trial Study Team. Trastuzumab after adjuvant chemotherapy in HER2-positive breast cancer.N Engl J Med 2005;353: 1659-1672.

31. Perez EA, Romond EH, Suman VJ, et al. Four-year follow-up of trastuzumab plus adjuvant chemotherapy for operable human epidermal growth factor receptor 2-positive breast cancer: joint analysis of data from NCCTG N9831 and NSABP B-31. J Clin Oncol 2011;29:3366-3373.
32. Smith I, Procter M, Gelber RD, et al. HERA study team. 2-year follow-up of trastuzumab after adjuvant chemotherapy in HER-2-positive breast cancer: a randomised controlled trial. Lancet 2007;369:29-36.

33. Yin W, Jiang Y, Shen Z, Shao Z, Lu J. Trastuzumab in the adjuvant treatment of HER-2-positive early breast cancer patients: a meta-analysis of published randomized controlled trials. PLoS One 2011;6: e21030.

34. Steinman S, Wang J, Bourne P, Yang Q, Tang P Expression of cytokeratin markers, ER-alpha, PR, HER-2/neu, and EGFR in pure ductal carcinoma in situ (DCIS) and DCIS with co-existing invasive ductal carcinoma (IDC) of the breast. Ann Clin Lab Sci 2007;37:127-134.

35. lakovlev V, Arneson N, Wong V, et al. Genomic differences between pure ductal carcinoma in situ of the breast and that associated with invasive disease: a calibrated aCGH study. Clin Cancer Res 2008; 14:4446-4454.

36. Farabegoli F, Champeme M, Bieche I, et al. Genetic pathways in the evolution of breast ductal carcinoma in situ. J Pathol 2001;196:280-286.

37. H Wong, S Lau, T Yau1, P Cheung and R J Epstein. Presence of an in situ component is associated with reduced biological aggressiveness of size-matched invasive breast cancer. $\mathrm{Br} J$ Cancer 2010;102: 1391-1396. 